\title{
EARLY MEDIEVAL RIVETED AXE-SHAPED BARS FROM TRNOVEC NAD VÁHOM
}

\author{
V L A D I M ÍR T U R Č A N
}

Two early medieval iron axe-shaped currency bars are published in this article for the first time. One of them was formed by two riveted pieces. This was a rather uncommon technological adjustment for this period.

Keywords: Slovakia, Early Middle Ages, axe-shaped bar.

Iron axe-shaped bars were an intrinsic element of the Great Moravian material culture. Although often the bars are found damaged or broken, measurements indicate that the weights and dimensions of the bars were standardised (Bialekovál Tirpáková 1989; Tirpáková/Bialeková/Vlkolinská 1989, 427-443). In the literature, the bars are dated back to the period between the end of the $8^{\text {th }} \mathrm{c}$. and the beginning of the $10^{\text {th }}$ c. (Hájnik 2019, 119, 120). Most of the bars come from depots and are virtually absent in graves - although there are single finds from graves.

The Slovak National Museum - Archaeological Museum in Bratislava has in its collection a pair of overlooked bars described as coming from Trnovec nad Váhom, Šala district, without any further annotation. The village of Trnovec nad Váhom is located in the eastern part of the Danube Basin, on the left bank of the river Váh. The early medieval settlement in the village is confirmed by the presence of a settlement feature dated back to the $7^{\text {th }}-8^{\text {th }} \mathrm{c}$. (Bielich 2007) and an extensive cemetery with inhumation graves used in the $9^{\text {th }}$ and $10^{\text {th }}$ c. (Hanuliak 2004, 277; Točík 1971, 137-184).

If the description placed on the bag is correct, the bars can be considered as consistent with abundant finds from the low and middle sections of the Váh and Nitra rivers. A great density of the bars finds is also recorded in southern Moravia (Fig. 1).

\section{DESCRIPTION}

1. An iron axe-shaped bar with a pointed, grooved and bent back, a cut-through square punch, longitudinal lobes along the edges with a longitudinal leaf and a rounded blade. Dimensions of the item: Length
$32.6 \mathrm{~cm}$, maximum width $4.7 \mathrm{~cm}$, the leaf thickness $0.4 \mathrm{~cm}$. The opening is $0.9 \times 0.6 \mathrm{~cm}$. The bar weighs $186.731 \mathrm{~g}^{1}$ (Fig. 2: 1) and is deposited in the Slovak National Museum - Archaeological Museum in Bratislava (no. AP 68 407).

2. An iron axe-shaped bar with a rounded back, a cutthrough square punch longitudinal lobes along the edges with a longitudinal leaf and a rounded blade. The leaf consists of two parts roughly joint with a rivet. Dimensions of the item: Length $31.4 \mathrm{~cm}$, maximum width $4.4 \mathrm{~cm}$, the leaf thickness $0.4 \mathrm{~cm}$. The opening is $1.2 \times$ $0.8 \mathrm{~cm}$. The leaf length $16.5 \mathrm{~cm}$, the rear length $16.4 \mathrm{~cm}$, the rivet dimensions $1.3 \times 0.9 \mathrm{~cm}$. The overlap length 2.1 $\mathrm{cm}$. The bar weighs $183.97 \mathrm{~g}$ (Fig. 2: 2-5) and is deposited in the Slovak National Museum - Archaeological Museum in Bratislava (no. AP 68 408).

According to the classification by R. Pleiner and D. Bialeková, the bars from Trnovec nad Váhom could be attributed to the II. class (Bialeková/Turčan 2007, fig. 9; Pleiner 1961, 426) and belong to the longest and heaviest specimens of this class.

One of the finds consists of parts of two different bars joint roughly in the middle with a rivet (Fig. 2: $2-5)$. The riveting method has been known already in the Bronze Age (Felcan/Stegmann-Rajtár/Tirpák 2019, 146) and remained in use also in the Middle Ages as confirmed, for instance, by riveting of iron cauldrons (Dostál 1975, 228, 229). Occasionally, the method was also used to fix damaged items such as scythes (Borzová/Pieta/Jakubčinová 2020, 38, pl. XX: 5; XXIV: 1, 5). It is a rather unusual method of fixing bars. However, a similar riveting could have been used to fix a bar from Bojná (Pieta/Ruttkay 2007, fig. 9: 10). The drawing and the preliminary analysis of the item, however, do not allow drawing more exact conclusions.

Spectral surface Roentgen analysis of the bars from Trnavec showed that the rivet contains

1 Weight after basic cleaning and before conservation. 


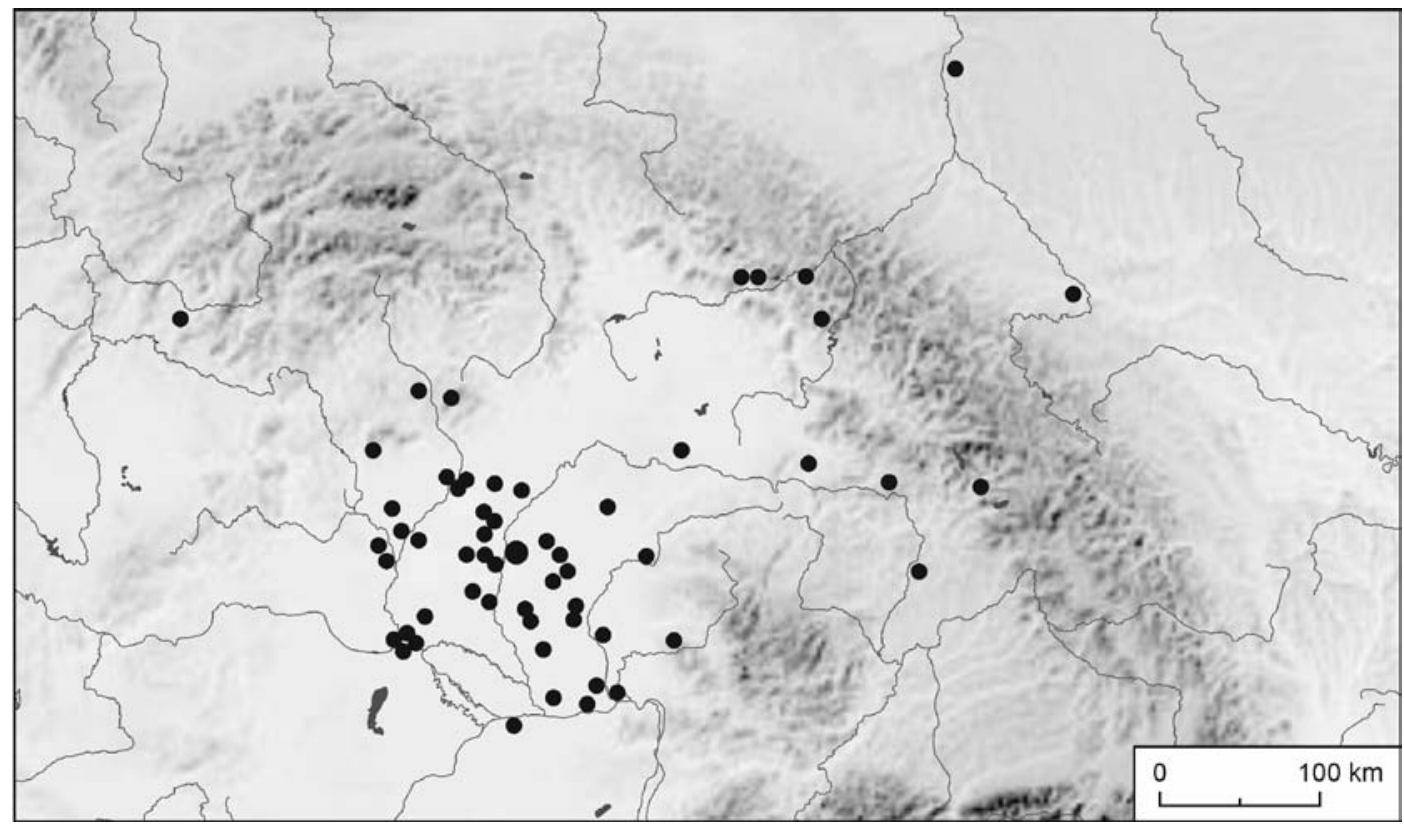

Fig. 1. Distribution of early medieval axe-shaped bars. The larger circle: Trnovec nad Váhom (based on Bialeková 2000, 201).

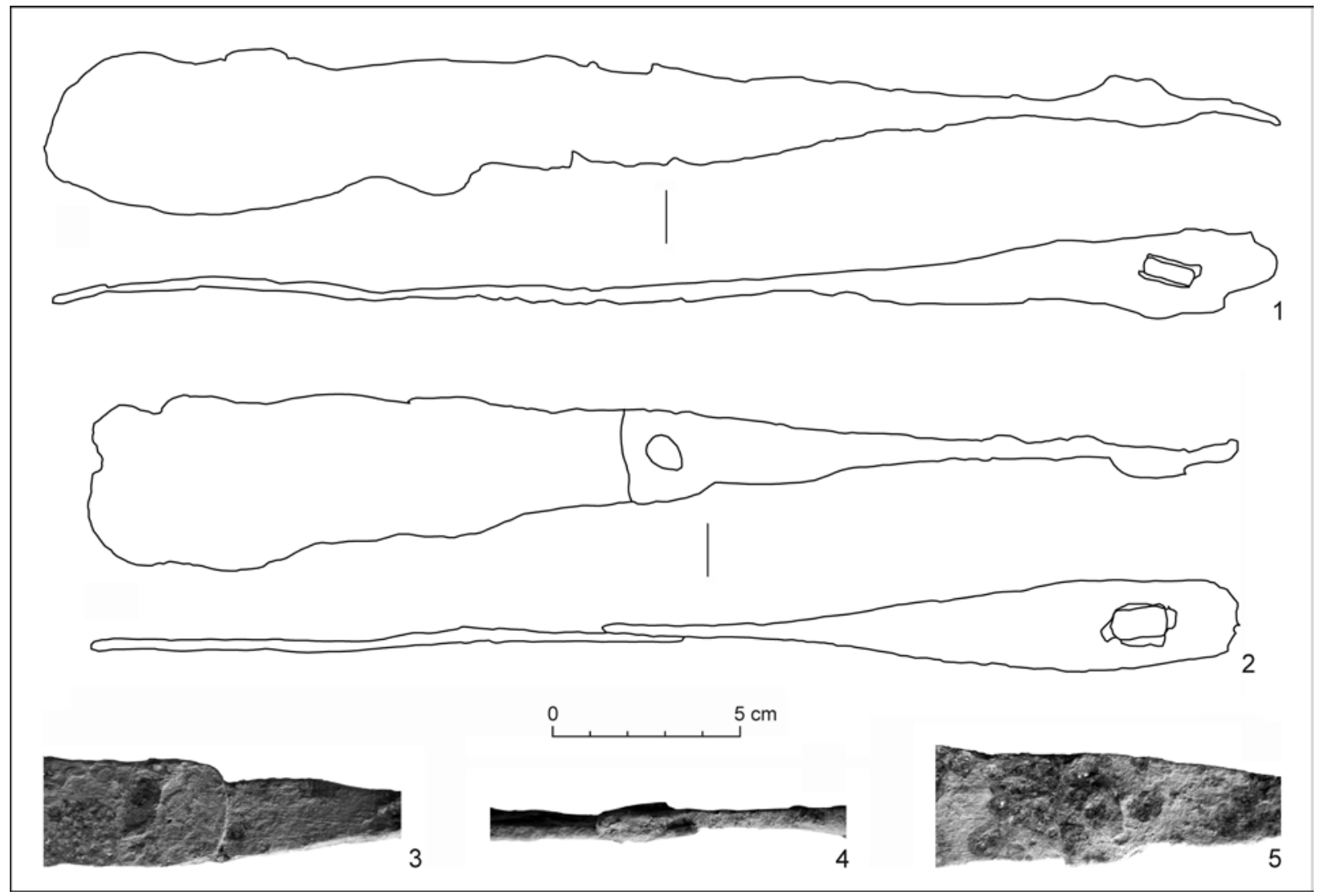

Fig. 2. Trnovec nad Váhom. 1, 2 - iron bars; 3-5 details of bar no. 2. 


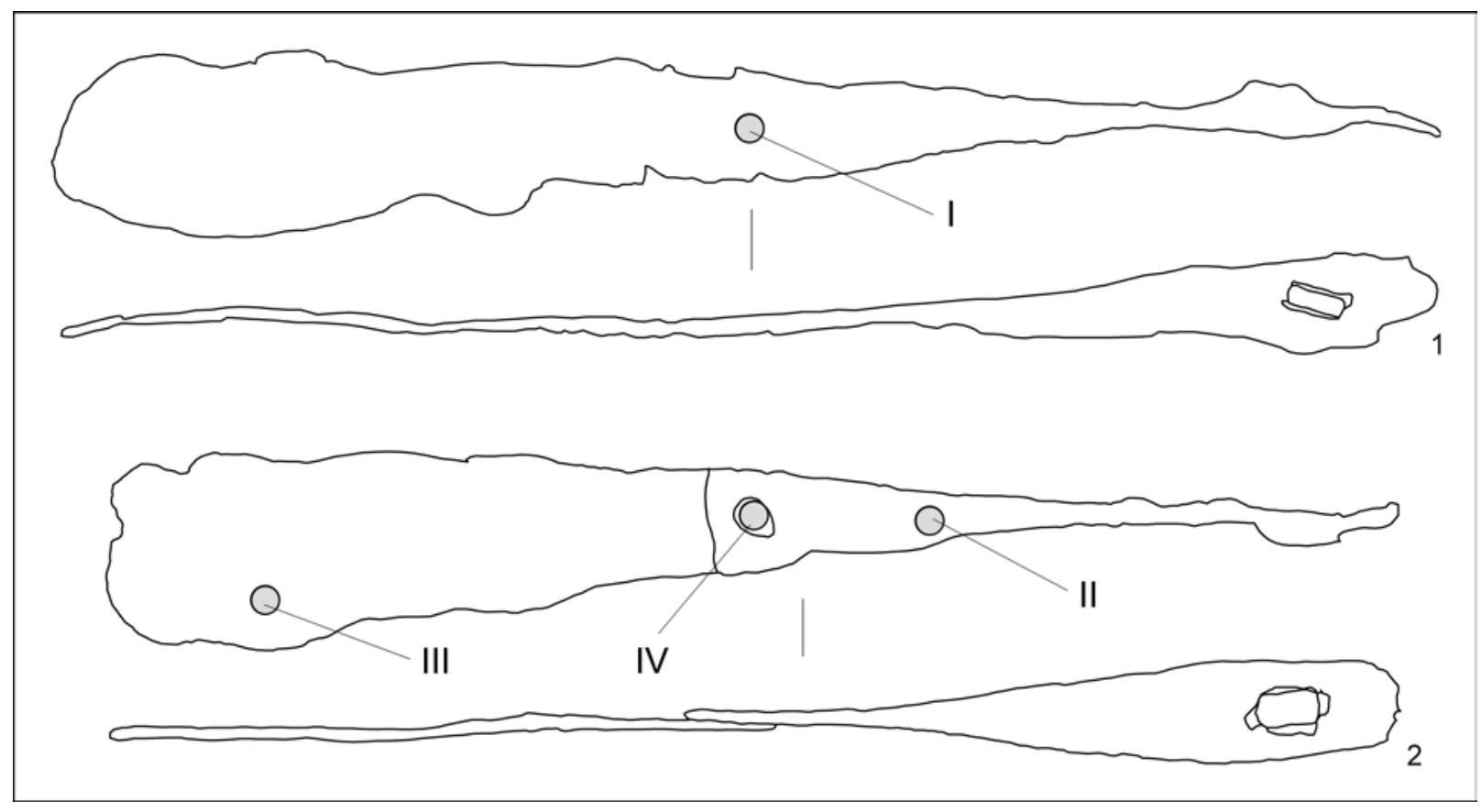

Fig. 3. Trnovec nad Váhom. Point measurements by spectral surface analysis.

Tab. 1. Trnovec nad Váhom. Results of point measurements by spectral surface analysis. The numbers are in accordance with Fig. 3.

\begin{tabular}{|l|c|c|c|c|c|c|c|}
\hline \multicolumn{1}{|c|}{ Iron bars } & $\mathrm{Fe}$ & $\mathrm{Co}$ & $\mathrm{Pb}$ & $\mathrm{Mo}$ & $\mathrm{Cu}$ & $\mathrm{Ni}$ & $\mathrm{Zr}$ \\
\hline Bar 1, point I & 99.72 & - & - & 0.023 & 0.055 & - & - \\
Bar 2, point II & 99.60 & - & - & - & 0.039 & 0.218 & - \\
Bar 2, point III & 99.69 & - & - & - & 0.124 & - & - \\
Bar 2, point IV (rivet) & 99.33 & 0.304 & 0.016 & 0.041 & - & 0.192 & 0.010 \\
\hline
\end{tabular}

Spectral surface Roentgen analysis was made using the XRF NITON XL3t unit. Manufacturer: Thermo Fisher Scientific, NITON, USA (the analysis was performed by R. Čambal, The Slovak National Museum - Archaeological Museum in Bratislava).

a different proportion of impurities than the bars (Fig. 3; Tab. 1). ${ }^{2}$ This indicates that the rivet comes from a different source as the bars - either in terms of the raw material it was made of or was made in a different workshop.

In the literature, there are two competing interpretations concerning the iron axe-shaped bars. Some of the researchers believe that bars were equivalent to money or a pre-monetary currency (Bialeková1990, 99; Galuška 2017, 198; Hájnik 2019, 141; Pleiner1961, 442; Pošvár̆ 1963, 137; Žigo 2017, 26,
27). Others question this hypothesis (Curta 2011, 318; Harvát 2019, 16-19; Macháček 2012, 781; Štefan 2011, 343).

The reason, however, why two damaged bars were combined into one could be sought only in the bars having a standardised market function that required specific weight and shape. It would be difficult to find another reason to repair the bar. Therefore, we can say that the bar from Trnovec nad Váhom contributed considerable weight to the debate about the function of these specific early medieval finds.

\footnotetext{
2 I would like to thank R. Čambal for the analysis.
} 


\section{BIBLIOGRAPHY}

Bialeková 1990 - D. Bialeková: Sekerovité hrivny a ich väzba na ekonomické a sociálne prostredie Slovanov. In: L. Galuška (zost.): Staroměstská výročí. Sborník př́ispěvků ze slavnostního zasedání u př́ležitosti 40 let archeologických výzkumů Moravského muzea ve Starém Městě a výročí objevu proní velkomoravskézděnéstavby ve Starém Městě Na valách, Uherské Hradiště, 7.-8. září 1988. Brno 1990, 99-119.

Bialeková 2000 - D. Bialeková: Eisenbarren. In: A. Wieczorek/H.-M. Hinz (Hrsg.): Europas mitte um 1000. Beiträge zur Geschichte, Kunst und Archäologie. Band 1. Stuttgart 2000, 201, 202.

Bialeková/Tirpáková 1989 - D. Bialeková/A. Tirpáková: K otázke funkčnosti sekerovitých hrivien z Pobedima z hladiska ich metrologických hodnôt. Slovenská numizmatika 10, 1989, 89-96.

Bialeková/Turčan 2007 - D. Bialeková/V. Turčan: Nový typ slovanských sekerovitých hrivien a ich metalografická analýza. In: V. Hašek/R. Nekuda/M. Ruttkay (eds.): Ve službách archeologie 2. Brno 2007, 151-158.

Bielich 2007 - M. Bielich: Včasnoslovanské nálezy z Trnovca nad Váhom. AVANS 2005, 2007, 54.

Borzová/Pieta/Jakubčinová 2020 - Z. Borzová/K. Pieta/M. Jakubčinová: Bojná 3. Polnohospodárske náradie z hradiska Valy a jeho zázemia. Archaeologica Slovaca Monographiae. Fontes 29. Nitra 2020.

Curta 2011 - F. Curta: New Remarks on Early Medieval Hoards of Iron Implements and Weapons. In: J. Macháček/Š. Ungerman (Hrsg.): Frühgeschichtliche Zentralorte in Mitteleuropa. Studien zur Archäologie Europas. Band 14. Bonn 2011, 309-332.

Dostál 1975 - B. Dostál: Břeclav-Pohansko IV. Velkomoravský velmožský dvorec. Spisy University J. E. Purkyně v Brně, Filosofická fakulta. Brno 1975.

Felcan/Stegmann-Rajtár/Tirpák 2019 - M. Felcan/S. Stegmann-Rajtár/J. Tirpák: Nové poznatky ku konštrukciám a technológiám výroby šperku z doby halštatskej zo Smoleníc-Molpíra. In: L. Benediková/G. Březinová/E. Horváthová/S. Stegmann-Rajtár (eds.): Fragmenty času. Venované Elene Miroššayovej k 70. narodeninám. Študijné zvesti AÚ SAV - Supplementum 1. Nitra 2019, 139-155. DOI: https://doi.org/10.31577/szausav.2019.suppl.1.8.
Galuška 2017 - L. Galuška: Slované - stopy předků. O Moravě v 6.-10. století. Brno 2017.

Hájnik 2019 - J. Hájnik: Včasnostredoveké sekerovité hrivny z územia strednej Európy. Musaica archaeologica 4/2, 2019, 111-172.

Hanuliak 2004 - M. Hanuliak: Vel'komoravské pohrebiská. Pochovávanie v 9.-10. storočí na území Slovenska. Archaeologica Slovaca Monographiae. Studia 8. Nitra 2004.

Harvát 2019 - M. Harvát: „,... iactitant se magnitudine pecuniae“. Otázka platobných prostriedkov na mojmírovskej Morave. Acta historica Neosoliensia 22/1, 2019, 4-28.

Macháček 2012 - J. Macháček: „Velkomoravský stát“ - kontraverze středoeuropské medievalistiky. Archeologické rozhledy 64, 2012, 775-787.

Pieta/Ruttkay 2007 - K. Pieta/M. Ruttkay: Bojná - mocenské a christianizačné centrum Nitrianskeho kniežatstva. Predbežná správa. In: K. Pieta/A. Ruttkay/M. Ruttkay (eds.): Bojná. Hospodárske a politické centrum Nitrianskeho kniežatstva. Archaeologica Slovaca Monographiae. Studia 9. Nitra 2007, 21-70.

Pleiner 1961 - R. Pleiner: Slovanské sekerovité hřivny. Slovenská archeológia 9, 1961, 405-450.

Pošvář 1963 - J. Pošvář: Velkomoravské železné hrivny jako platidlo. Numismatické listy 18/5, 1963, 134-144.

Štefan 2011 - I. Štefan: Great Moravia. Statehood and Archaeology. In: J. Macháček/Š. Ungerman (Hrsg.): Frühgeschichtliche Zentralorte in Mitteleuropa. Studien zur Archäologie Europas. Band 14. Bonn 2011, 333-354.

Tirpáková/Bialeková/Vlkolinská 1989 - A. Tirpáková/D. Bialeková/I. Vlkolinská: The Application of Some Mathematic-statistical Methods in Solving the Possibility of Exploitation of Roman Measures in Manufacturing of Slavic Axe-Shaped Currency Bars and Pottery. Slovenská archeológia 37, 1989, 427-450.

Točík 1971 - A. Točík: Flachgräberfelder aus dem IX. und X. Jahrhundert in der Südwestslowakei. Slovenská archeológia 19, 1971, 135-276.

Žigo 2017 - P. Žigo: Hrivna - motivácia jej pomenovania, významy a ekvivalenty $\mathrm{v}$ staroslovienskych textoch. Musaica archaelogica 2/2, 2017, 23-36.

Manuscript accepted 17. 7. 2021

Translated by Magdalena Adamus

PhDr. Vladimír Turčan

SNM - Archeologické múzeum

Žižkova 12

SK - 81006 Bratislava

vladimir.turcan@snm.sk 